Journal of Indonesian Economy and Business

Volume 35, Number 1, 2020, 1 - 16

\title{
THE EFFICIENY OF VILLAGE GOVERNMENT SPENDING IN INDONESIA: A META-FRONTIER ANALYSIS
}

\author{
Tengku Munawar Chalii ${ }^{1,2 *}$ \\ ${ }^{1}$ Department of Comparative Public Policy, Osaka School of International Public Policy, Osaka \\ University, Osaka, 5600043, Japan. \\ ${ }^{2}$ School of Architecture, Planning, and Policy Development, Institut Teknologi Bandung, Bandung, \\ 40132, Indonesia
}

\begin{tabular}{|c|c|}
\hline ABSTRACT & ARTICLE INFO \\
\hline $\begin{array}{l}\text { Introduction: This study aims to measure the efficiency of village } \\
\text { government spending and examine the effects of village transfers (Dana } \\
\text { Desa) and institutional properties on its efficiency. Background } \\
\text { Problems: The village law has endowed extra grants to village } \\
\text { governments, which questions if the villages are prepared to adequately } \\
\text { handle large increases in funding. Novelty: While previous studies } \\
\text { address the misappropriation in spending within the municipal } \\
\text { dimension, this study explores the spending efficiency of the autonomous } \\
\text { sub-municipal governments and explains the impacts of both lump-sum } \\
\text { grants and bureaucracy factors on spending efficiency. Research } \\
\text { Methods: This study analyzes the Indonesian } 2014 \text { Village Govern- } \\
\text { ments' dataset, using the meta-cost frontier in order to measure village } \\
\text { spending efficiency, then it probes the causal impacts of endowed fiscal } \\
\text { transfers and bureaucratic factors on the obtained efficiency. Findings/ } \\
\text { Results: The results suggest that granting direct transfers would } \\
\text { exacerbate the spending inefficiencies of autonomous villages. Adminis- } \\
\text { trative factors such as a large bureaucracy and a lack of bureaucratic } \\
\text { capacity within the body of village governments positively affect } \\
\text { spending inefficiencies. Conclusion: The result of this research reflects } \\
\text { that there is a need to evaluate the village governance policy to increase } \\
\text { spending efficiencies, specifically focusing on the adequacy of village } \\
\text { institutions to handle village transfers. }\end{array}$ & $\begin{array}{l}\text { Article history: } \\
\text { Received } 1 \text { April } 2019 \\
\text { Received in revised form } \\
\text { 5 September } 2019 \\
\text { Accepted } 23 \text { January } 2020\end{array}$ \\
\hline
\end{tabular}

\footnotetext{
* Corresponding Author at Department of Comparative Public Policy, Osaka School of International Public Policy, Osaka University, Machikaneyama 1-31, Toyonaka, Osaka, 5600043, Japan.

E-mail address: c-tengku@osipp.osaka-u.ac.jp
} 


\section{INTRODUCTION}

Indonesian decentralization reform is gradually progressing, with the fragmentation of responsibilities within government authorities (Smoke and Lewis, 1996). This decentralization reform comes with various law packages, the most recent being Law 6/2014 on Village Government. Its implementation is progressing nationwide and has been implemented at the sub-municipal level. The law formalizes the creation of village governments, which are quasi-federal structures in the articulation of democratic legitimacy and public service provisions at a sub-municipal level (Hlepas, Kersting, Kuhlmann, Swianiewicz \& Teles, 2018).

The village law greatly increases village budgets, injecting an additional 21 trillion rupiah (about US\$ 1.5 billion) into village budgets in 2014 as top-down transfers (Aspinall \& Rohman, 2017). These transfers account more than $70 \%$ of rural/village government revenues. Given the newness of such large endowments from central sources, there have been somewhat limited studies into village financial management systems that question their preparedness to adequately handle large increases in funding. The qualitative study from the Corruption Eradication Commission finds that unclear regulations and guidance about village transfer spending, and the lack of capacity of the executive body in ruralgovernments, have potentially caused government expenditure misallocations. ${ }^{1}$ Antlöv, Wetterberg \& Dharmawan (2016) argue that the village budget is usually overstated. From the experience of the National Program of Village Empowerment from 2006 to 2014, they found that there is a significant gap between a village's proposed budget and the budget's realization.
Lewis (2015) provides empirical evidence of the flaw in village transfers, for example, poor villages get fewer transfers. However, there is no study to explore the potential abuse of the transfers from the side of the village governments' expenditure. The studies on addressing misappropriation in spending are abundant but limited to the dimension of the sub-national or municipal level (e.g. Akai, Sato, \& Yamashita, 2001; Boetti, Piacenza, \& Turati, 2012; De Borger \& Kerstens, 1996).

Thus, this paper tries to fill the gap above by investigating the efficiency of village government spending post the implementation of Law 6/2014 on Village Government. By analyzing the parametric spending inefficiency from 80,179 Indonesian villages in 2014 , the paper shows that autonomous villages have higher spending efficiencies than the villages with nonautonomous status. The autonomous villages are the villages with independent governance that have the rights to village transfers. Meanwhile, the non-autonomous villages (kelurahan) are sub-governments under the responsibility of the municipal governments (Martinez-Bravo, 2014). It appears that the independency to govern promotes the efficiency of public spending. Likewise, granting direct top-down transfers improves villages' government spending efficiency, albeit bureaucracy factors such as ballooning bureaucracy and the lack of the village officials' capacity worsen efficiency.

The first half of this article discusses the background and framework of the village decentralization framework and its transfers, together with theoretical support for the effects of bureaucracy on its efficiency. The second half of the paper provides empirical results.

\footnotetext{
${ }^{1}$ Report from Indonesia Corruption Eradication Commission (2015) titled "village fund management: allocation of village fund and transfers" (Pengelolaan Keuangan Desa: Alokasi Dana Desadan Dana Desa).
} 
Table 1. Positioning of this study

\begin{tabular}{|c|c|c|c|}
\hline Article & Sample & Method & Key findings \\
\hline $\begin{array}{l}\text { Boetti, Piacenza, \& } \\
\text { Turatti (2012) }\end{array}$ & $\begin{array}{l}2005 \text { Italian } \\
\text { municipalities }\end{array}$ & SFA \& DEA & $\begin{array}{l}\text { Fiscally autonomous municipal is more } \\
\text { efficient }\end{array}$ \\
\hline $\begin{array}{l}\text { De Borger \& } \\
\text { Kerstens (1996) }\end{array}$ & $\begin{array}{l}\text { Belgium } \\
\text { municipalities }\end{array}$ & FDH, DEA, \& SF & $\begin{array}{l}\text { - Unconditional grants reduce municipal } \\
\text { efficiency } \\
\text { - Education and tax rates increase } \\
\text { efficiency }\end{array}$ \\
\hline $\begin{array}{l}\text { Borge, Falch, \& } \\
\text { Tovmo (2008) }\end{array}$ & $\begin{array}{l}\text { Norwegian } \\
\text { municipalities }\end{array}$ & $\begin{array}{l}\text { Service Efficiency (Gap of } \\
\text { Baseline \& production) }\end{array}$ & $\begin{array}{l}\text { - Domination of political parties increase } \\
\text { efficiency } \\
\text { - High revenue led to less efficient }\end{array}$ \\
\hline This study & $\begin{array}{l}\text { Indonesian sub- } \\
\text { municipalities } \\
\text { (village } \\
\text { governments) }\end{array}$ & Meta-cost frontier & $\begin{array}{l}\text { - Grants to villages increase efficiency } \\
\text { - Autonomous villages are more efficient } \\
\text { - Bureaucracy sizes reduce efficiency }\end{array}$ \\
\hline
\end{tabular}

\section{LITERATURE REVIEW}

\section{Indonesian Village Decentralization Framework}

Indonesia's decentralization policy began after the collapse of the authoritarian regime of the Soeharto era in 1998. The enacted decentralization law in 1999enforced the full transfer of authority from central to local governments. There are two significant amendments to the 1999 decentralization law; Law 32/2004 on Local Government and Law 23/2014 on Local Governance. Despite the progressive stage of decentralization, the central and local governments are still at the stage of finding the proper fragmentation for the balance of authority (Aspinall, 2003). The granting of autonomy was supposed to reduce development inequality between the central and local governments, and between the rich and poor regions (Roudo \& Chalil, 2016). However, the rising inequality between rural and urban areas propels the public demands for expanding decentralization to the village level (Antlöv, 2003).

As a hurried response, the government introduced Law 6/2014 on Village Government. The law acknowledges that village governments (pemerintahan desa) have the right to govern and to provide public services based on their own needs and circumstances, within their administrative boundaries.

Village governments have responsibilities to provide certain public services for their "local" indigenous people. Government Regulation $43 / 2014$ provides the details of the village governments' authority, which are: (1) basic public services (health and education), for instance, cram schools (taman bacaan), maternal health posts, emergency units (posyandu), or others; (2) village-scale infrastructure and transportation, for instance, agro-irrigation, local markets, village roads, and others. Following these authorities and functions, the central government decided to transfer the funds using an intergovernmental transfer scheme.

Law 6/2014 obliges the central government to share at least $10 \%$ of the total fiscal transfers in the national budget with the village governments. ${ }^{2}$ The use of village transfers is not

\footnotetext{
${ }^{2}$ The history of village budgets started from the first decentralization policy in Law 22/1999. The law stated that villages could receive government transfers for their financing. Further, it was also endorsed in Government Regulation 72/2005, which authorizes the transfers to villages from municipal accounts. However, the transfers are not applied thoroughly in all regions. Rising demands for village autonomy rights in the recent development
} 
explicit; however, $30 \%$ of these transfers should go to village government operations and $70 \%$ for capital development spending. ${ }^{3}$ Lewis (2015) shows the calculation for village transfers, which can be perceived as a general formula with several demographic and geographic variables. Based on the calculation process, the nature of village transfers is close to lump-sum grants since they do not represent the real needs for the villages' development. Furthermore, Lewis (2015) suggests that village transfers are unequally distributed. He finds that villages with high levels of poverty receive less funding than villages with greater access to funding, especially oil and gas transfers. In his remarks, the villages' service responsibilities are unclearly defined and the villages' public financial systems are inadequately prepared to handle the transfers.

On the other hand, Maharjan (2014) suggests that the inadequate capacity within the village governments is a result of the lack of resources and budgets to train the village apparatuses. Despite the limitation of resources and capacity, village communities give above average scores for the performance of their villages' apparatuses for capturing the villages' needs, providing services, and accountability. He remarks that future village transfers should be increased to overcome the local problems.

The above literature shows a problem with the village transfers. First, the village transfers potentially exacerbate the efficiency of public services due to the inadequate capacity of the villages' governments. Second, the village transfers are essential to source funding for the villages' development. The following section explains the theoretical underpinning of the impact of village transfers and village capacity's relationship with spending efficiency.

enforced the stipulation of Law 6/2014 that mandated the village transfers.

${ }^{3}$ It is mandated on Government Regulation 43/2014.

\section{Theoretical Underpinning: Maximizing Bureaucracy Model}

The model for maximizing bureaucracy (Niskanen, 1968) is appropriate to explain the impacts of fiscal transfers and institutions on spending efficiency. The model starts with the assumption that the bureaucracy maximizes the total budget given the utility demands and costs, subject to production constraints. The total budget is derived from the marginal values of taxpayers with the decreasing marginal utility of public goods' consumption $Q$.

$$
T B=a Q-b Q^{2}
$$

Then the bureaucrats who provide public goods face a constraint, in that the total cost of providing public goods must not exceed the total budget $(T B)$, the "no fat" bureaucracy indicates that the total budget should cover the minimum total costs (Niskanen, 1968). Assuming that the aggregate cost function has a linear production ${ }^{4}$ :

$$
T C=c Q
$$

In Figure 2, the equilibrium $Q$ is located at $=\frac{a-c}{b}$, and the maximized budget leads to an equilibrium $Q=\frac{a-c}{2 b}$. Moesen \& Van Cauwenberge (2000) extend this model by adding a fiscal residuum as a difference between the budget and the costs incurred. They explore the later version of Niskanen's model, where bureaucrats are inefficient producers, generating a utility for bureaucrats that take the form of, for example, coffee breaks, political appointments, and complicated procedures. The utility curve of bureaucrats intersects the fiscal residuum curve (in the lower panel, Figure 2), and produces public goods at level $Q^{*}$, which is lower than the social optimum level $\left(Q=\frac{a-c}{b}\right)$.

\footnotetext{
${ }^{4} \mathrm{I}$ assume a linear model to simplify the intuition. By assuming the aggregate cost function is linear, then the production cost for bureaucrats is uniform. One could expect that the sign is positive to ensure a positive scale economy, which indicates that decentralization increases the size of government.
} 


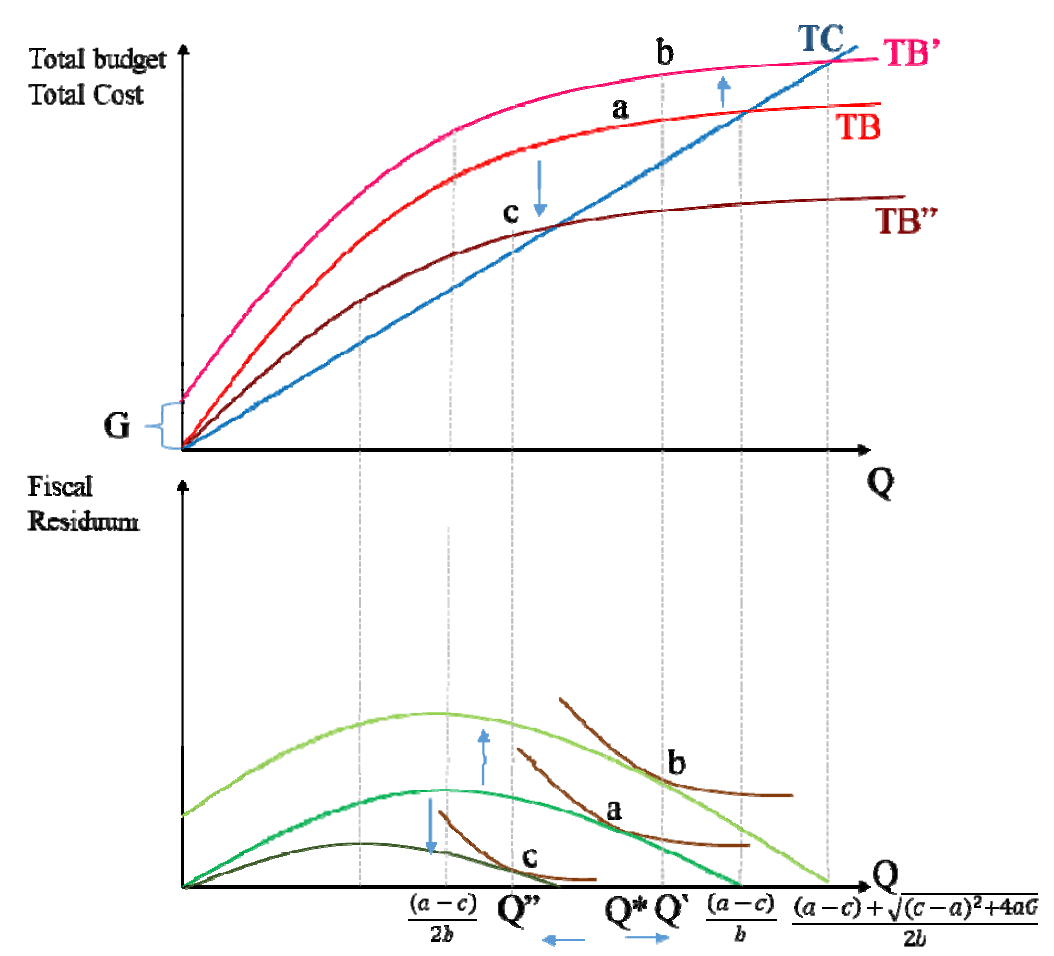

Source: Moesen \& Van Vauwenberge (2000) with author's modification

Figure 1. Effect of Bureaucracy's Size and Lump Sum Transfers on Government Efficiency

\section{Effects of Unconditional Grants}

In the case of unconditional grants such as village transfers, the central government endows village bureaucrats with an extra budget, to the amount $G$ of the total budget $(T B)$. The shifting of the total budget increases the socially optimal public goods provided, where $Q^{* *}=$ $\frac{(a-c)+\sqrt{(a-c)^{2}+4 b G}}{2 a}$, which is greater than $Q$. However, the maximized budget is still at the level within Niskanen's model where $Q=\frac{a-c}{2 b}$. The indifference curve of bureaucraticutility shifts up as the fiscal residuum become larger, the intersection (at the point $b$ ) leads to a new choice for the bureaucrats to produce $Q$ '. The effects of an unconditional grant increases government expenditures and the provided public goods; implying higher output while holding the level of efficiency equal. Now we set the hypothesis as described below.

H1: Unconditional grants (village transfers) improve government efficiency

\section{Effects of Bureaucracy Size and Capacity}

First, consider the bureaucrat performance function to be a function of the adequacy of bureaucrats (capability) and the number of officers (bureaucracy size); each denoted as $C$ and $B$. The performance of the bureau is a monotonic increase in bureaucratic capability, which is provided by training, education, and experience from operating the apparatus. Further, the bureaucracy's size has a diminishing return for bureaucratic performance. Better performance by the bureaucracy leads to taxpayers' satisfaction, so the marginal values of the taxpayer $(\mathrm{V})$ become:

$$
\mathrm{V}=\mathrm{a}-\frac{Q}{F(B, C)}
$$

Where $F(B, C)$ is the performance of the bureaucratic function. The total budget for the bureaucrats becomes:

$$
\mathrm{TB}=\mathrm{aQ}-\frac{\mathrm{Q}^{2}}{2 F(B, C)}
$$


The effect of increasing the capacity of the bureaucrats will increase the total budget, since:

$$
\frac{\partial \mathrm{TB}}{\partial \mathrm{C}}=\frac{\partial \mathrm{F}(\mathrm{B}, \mathrm{C})}{\partial \mathrm{C}} \frac{\partial \mathrm{TB}}{\partial \mathrm{F}(\mathrm{B}, \mathrm{C})}=\frac{1}{2} \frac{\partial \mathrm{F}(\mathrm{B}, \mathrm{C})}{\partial \mathrm{C}}\left[\frac{Q}{\mathrm{~F}(\mathrm{~B}, \mathrm{C})}\right]^{2}
$$

Hence, the performance of the bureaucrats is a monotonic increase, so $\frac{\partial \mathrm{F}(\mathrm{B}, \mathrm{C})}{\partial \mathrm{C}}$ is positive. Therefore, $T B$ increases, leading to a new equilibrium $Q$ " where the provided service goods are larger than $Q$ in Niskanen's model. Now we set the hypothesis as described below.

H2: Bureaucracy's capacity improves government efficiency

In contrast, bureaucracy's size has a diminishing return on bureaucratic performance, which changes the sign.

$$
\frac{\partial \mathrm{TB}}{\partial \mathrm{B}}=\frac{\partial \mathrm{F}(\mathrm{B}, \mathrm{C})}{\partial \mathrm{B}} \frac{\partial \mathrm{TB}}{\partial \mathrm{F}(\mathrm{B}, \mathrm{C})}=-\frac{1}{2} \frac{\partial \mathrm{F}(\mathrm{B}, \mathrm{C})}{\partial \mathrm{B}}\left[\frac{Q}{\mathrm{~F}(\mathrm{~B}, \mathrm{C})}\right]^{2}
$$

The new equilibrium exists at the point $c$, the lower panel of Figure 2. Increasingthe bureaucracy's size decreases the total budget curve to $T B$ ”. By keeping the utility of the bureaucrats unchanged, the provided public goods falls to Q", which is lower than the initial Niskanen's model, Q*. Now we set the hypothesis as described below.

H3: Increasing the bureaucracy's size reduces government efficiency

The theoretical framework above demonstrates that extra budget funds increase the social optimal of providing public goods; conversely, the bureaucracy has two effects: increasing the size of the administration negatively affects the social optimal of delivering public goods; but bureaucratic quality creates a better condition. In the next step, these arguments are tested by using empirical data from Indonesian village governments.

\section{METHOD, DATA, AND ANALYSIS}

\section{Measuring the Cost Efficiency of Rural Government Expenditures}

The studies on measuring the efficiency of government are abundant (e.g., see: Akai, Sato, \& Yamashita, 2001; Battese \& Coelli, 1992; and Boetti, et al., 2012). For each $i$ producers, total expenditure $(E)$, the quantity of produced outputs, and the input price; the cost frontier is expressed as:

$$
E_{i} \geq C\left(y_{i}, w_{i} ; \beta\right) \exp \left(v_{i}\right)
$$

Where $E_{i}=w_{i} x_{i}=\sum_{n} w_{n i} x_{n i}$ is expenditure incurred by the producer $i, i=1,2, . ., I ; y_{i}$ is a vector of $N$ outputs produced by producer $i$, $C\left(y_{i}, w_{i} ; \beta\right)$ is the cost frontier, $w$ is the input price, which is assumed to be monetized, and $\beta$ is the vector parameters to be estimated; $\exp \left(v_{i}\right)$ is the random stochastic shocks that varies for each producer. $C E_{i}$ is the cost efficiency of producer $i$, which is evaluated as follows:

$$
C E_{i}=\frac{C\left(y_{i}, w_{i} ; \beta\right) \exp \left(v_{i}\right)}{E_{i}}
$$

Where cost efficiency is a ratio of the minimum cost attainable in an environment characterized by $\exp \left(v_{i}\right)$. Assumingthe equality of revenue and expenditure, procured expenditure is equal to minimum cost if $C E_{i}=1$. Ashortfall of observed expenditure to minimum feasible cost is shown by $0 \leq C E<1$ (Kumbhakar \& Lovell, 2000).

For the estimation strategy, this study employs stochasticfrontier analysis (SFA) which is later modified tometa-SFA. SFA is reasonably robust when applying a sizeable cross-sectional dataset compared with other frontier analysis, such as data envelopment analysis (DEA) (Hjalmarsson, Kumbhakar, \& Herhmati, 1996). 


\section{Model Specification}

The model specification follows Battesse \& Coelli (1992):

$$
\begin{aligned}
& \ln C_{i}=\beta_{i} \ln X_{i}+\varepsilon_{i} \\
& \varepsilon_{i}=\delta_{i}+\mu \\
& \delta_{i}=\alpha Z+\omega
\end{aligned}
$$

Where $C_{i}$ is the total revenues of village $i$, as a proxy of total expenditure, in this condition, procured expenditures should meet total revenues. $x_{i}$ represents output factors that are provided by ruralgovernments. $\mu$ is random noise, and $\delta$ is the inefficiency terms, both are i.i.d. The function is return to scale and follows the Cobb-Douglas rule. In the next step, the inefficiency terms are products of corruption, monitoring, size of the government (in matrix Z). For efficiency's measurement, the statisticprogramming measures cost inefficiency as:

$$
\mathrm{CE}_{\mathrm{i}}=\mathrm{E}\left\{\exp \left(-\mathrm{u}_{\mathrm{i}}\right) \mid \varepsilon_{\mathrm{i}}\right\}
$$

Where the estimated cost inefficiency has an exponential distribution, which varies from 1 (minimum cost) to infinity (Battesse \& Coelli, 1992). Following the formula of Khumbakar \& Lovell (2000), cost efficiency takes the form of the inverse of the estimated cost inefficiency:

$$
\mathrm{CE}_{\mathrm{i}}=\mathrm{E}\left\{\exp \left(\mathrm{u}_{\mathrm{i}}\right) \mid \varepsilon_{\mathrm{i}}\right\}
$$

Therefore, cost efficiency varies from 0 (perfectly inefficient) to 1 (perfectly efficient).

\section{Meta-Cost Frontier Approach}

The meta-cost frontier approach allows us to estimate the cost efficiency in different given groups within the data. The method of the metacost frontier is similar to the cost frontier's estimation but the meta-cost frontier estimates the efficiency by groups. Battese \& Rao's (2002) article presents the detailed methods. For $j$ groups, the cost frontier becomes:

$$
E_{i} \geq C\left(y_{i(j)}, w_{i(j)} ; \beta_{(j)}\right) \exp \left(v_{i(j)}\right)
$$

Parameters $w_{i(j)} ; \beta_{(j)}$ are governed under the meta-cost frontier $w_{i} ; \beta$ with the following restriction:

$$
w_{i(j)} ; \beta_{(j)} \leq w_{i} ; \beta
$$

Therefore, the evaluated cost efficiency (withingroup) becomes:

$$
C E_{i(j)}=\frac{C\left(y_{i(j)}, w_{i(j)} ; \beta_{(j)}\right) \exp \left(v_{i(j)}\right)}{E_{i(j)}}
$$

The following equation represents the evaluated estimated efficiency within $j$ groups:

$$
C E_{i(j)}=E\left\{\exp \left(u_{i(j)}\right) \mid \varepsilon_{i(j)}\right\}
$$

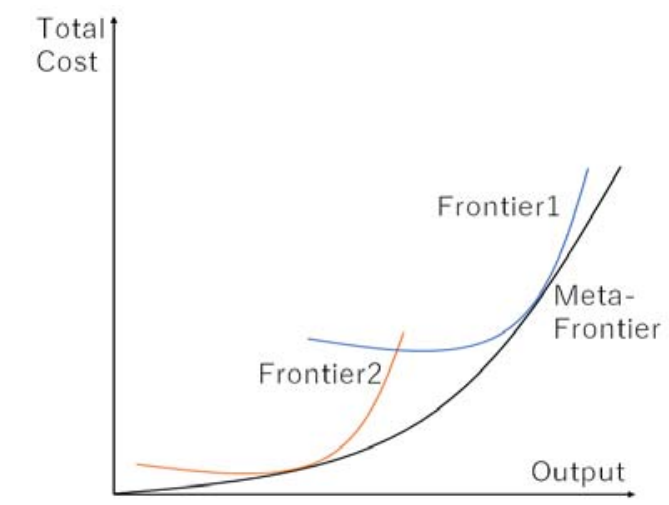

Source: Battese, Rao \& O’Donnell (2004) with author's modification

Figure 2. Illustration of Meta-Cost Frontier Analysis

Village governments can choose their administrative status, whether they want to be autonomous (village government) or not autonomous (kelurahan/urban communities). ${ }^{5}$ Since the village dataset contains all the sub-municipal governments, I divided the data into village and non-village groups. As the first step for each group, the calculation lists the sub-municipal governments which are the most inefficient, and the most efficient, in spending. The second step models the effect of bureaucracy on the inefficiency of ruralgovernments.

\footnotetext{
${ }^{5}$ Paragraph 1, article 11, Law 6/2014 mentions that villages can change their administrative status to urban communities (kelurahan) through the village government's initiation and considering the village community's aspirations.
} 


\section{Data Description}

The Indonesian Central Bureau of Statistics (BPS) provides an enormous dataset for the 2014 Village Development Survey (Potensi Desa 2014) covering all the village administrations in Indonesia (80,179 observations). The dataset is divided into two groups, the autonomous village (desa) group and the non-autonomous village (kelurahan) group. The autonomous villages account for $88.55 \%$ of the total observations and the non-autonomous villages account for $11.45 \%$. The employed variables are organized into three categories: expenditure $\left(E_{i}\right)$, output $\left(y_{i}\right)$, and efficiency variables $(Z)$.

Expenditure: Holding the equality, the total revenue of the village government is a proxy of its total expenditure. It is a sum of own-source revenue, grants/contributions from higher tiers of government, and village transfers.

Output: There are two approaches to output, first is the physical output approach and second is the expenditure approach. The variables are as follows:

a. Education infrastructure; is the sum of the schools build by village governments, including playgroups, informal elementary schools, local libraries (taman bacaan), training and vocation schools, and madrasas.

b. Health infrastructure; is the sum of maternal health posts, local polyclinics, drugstores, and integrated service posts (posyandu).

c. Religious infrastructure; is the sum of mosques, mushallas, churches, shrines, and other prayer buildings, to which the village government has contributed.

d. Village co-op; is the sum of the co-ops or unions for the village's economy and development, including village-integrated coops $(K U D)$, micro-industry and craft co-ops (kopinkra), micro-credit and banking co-ops (kospin), and other related co-ops or unions. e. Capital spending; expenditure for capital, land, assets or physical goods by the village government in the same year.

f. Overhead spending; expenditure for paying wages, salaries, offices and related spending for government operations.

g. Other spending; expenditure on other spending, that is, grants, tax, interest, and others.

\section{Efficiency Explanatory Variables}

a. Portion of micro-transfer; shares of the ruralmicro transfer to total revenue in a village;

b. Ad-hoc village representative institution; the institution functions as a parliament, consisting of community representatives, its authority includes legislation of the village's regulations; monitoring government plans, the budget and its execution; and it is a place for the community to voice their opinions and interests. The dataset is binary (one = representative available, zero = not available);

c. Village security officers; the number of security officers (hansip/linmas) hired by village governments. Registered village apparatus; thenumber of officials in the village government. Summation of both these variables serves as the proxy for the size of the government.

d. Education of village leader and education of village secretary; indicates the capacity of the village government. The ordinal data is explained by the following: (one $=$ never went to school; two = went to school but did not graduate from elementary school; three = elementary graduate; four $=$ junior high graduate; five $=$ high school graduate; six $=$ associate graduate; seven $=$ bachelor graduate; eight $=$ master's graduate; nine $=$ doctoral graduate).

Table 2 presents the statistical summary. 
Table 2. Statistical Summary of Dataset

\begin{tabular}{|c|c|c|c|c|}
\hline Variables & Mean & SD & Min & Max \\
\hline \multicolumn{5}{|l|}{ Input } \\
\hline Total village revenue & 312.86 & 530.19 & 0 & 17,282 \\
\hline \multicolumn{5}{|l|}{ (in million rupiah) } \\
\hline \multicolumn{5}{|l|}{ Output } \\
\hline $\begin{array}{l}\text { Educational infrastructure built under village gov`t authority (number } \\
\text { of building) }\end{array}$ & 2.72 & 4.24 & 0 & 129 \\
\hline $\begin{array}{l}\text { Health infrastructure built under village gov't authority (number of } \\
\text { building) }\end{array}$ & 4.57 & 5.01 & 0 & 104 \\
\hline $\begin{array}{l}\text { Religion related infrastructure built under village gov't authority } \\
\text { (number of building) }\end{array}$ & 11.1 & 14.2 & 0 & 219 \\
\hline Village co-ops & 0.88 & 2.64 & 0 & 101 \\
\hline \multicolumn{5}{|l|}{ Expenditure } \\
\hline Spending on capital, assets, land, buildings, etc. (million rupiah) & 132.80 & 574.27 & 0 & 9950 \\
\hline Spending for routine activities (wages, offices, electricity, phone, etc) & 130.33 & 295.61 & 0 & 9797 \\
\hline \multicolumn{5}{|l|}{ / overhead spending (million rupiah) } \\
\hline $\begin{array}{l}\text { Spending for others (ex. non-direct spending, grants, awards, tax, } \\
\text { interest, etc) }\end{array}$ & 51.81 & 252.07 & 0 & 9630 \\
\hline \multicolumn{5}{|l|}{ Exogenous variable } \\
\hline Portion of micro-transfer to village gov't revenue & 0.45 & 0.34 & 0 & 1 \\
\hline Existence of ad-hoc village representative's institution $(\mathrm{Y} / \mathrm{N})$ & 0.96 & 0.32 & 0 & 1 \\
\hline Number of village security officers & 12.64 & 14.97 & 0 & 210 \\
\hline Number of apparatus registered in village & 12.28 & 8.68 & 0 & 99 \\
\hline Education of village government's leader & 5.22 & 1.17 & 1 & 9 \\
\hline Education of village government's secretary & 5.34 & 1.08 & 1 & 9 \\
\hline Observation & \multicolumn{4}{|c|}{80,179} \\
\hline Autonomous villages (Desa) & \multicolumn{4}{|c|}{$71,000(88.55 \%)$} \\
\hline Non-autonomous villages (Kelurahan) & \multicolumn{4}{|c|}{$9179(11.45 \%)$} \\
\hline
\end{tabular}

\section{RESULTS AND DISCUSSION}

At first, the meta-cost frontier analysis estimates the cost efficiency of village governments' expenditure. The observations are classified into two groups; the first one is the (autonomous) village government and the second one is the urban community (kelurahan- non-autonomous). Each group has different decision-making processes since urban communities do not have autonomy for discretionary spending. After estimating the cost frontier curve for each group, a meta-cost frontier curve is constructed. There are two model approaches. Model (1) is the output-approach and model (2) is the expen- diture-approach, for the robustness check. ${ }^{6}$ Table 3 and Table 4 present the results respectively. The produced cost efficiency under exponential distribution has the maximum value of one for perfect efficiency. ${ }^{7}$

\footnotetext{
${ }^{6}$ Input price is indexed, since for the output approach mainly physical outputs are used as output variables. In Indonesia, physical outputs (construction, buildings, roads, etc.) have been standardized through government regulation. On the other hand, the expenditure approach does not necessarily impose an input price.

${ }^{7}$ Programming on SFA produced a different scale of cost efficiency, which follows the estimation technique by Battese and Coelli (1992) where $C E=\{1$,Infinity $\}$ where perfect efficiency takes the value as one. I scale the efficiency measurement by taking the inverse of CE, to be consistent with CE under Kumbhakar and Lovell's (2003) approach, where $\mathrm{CE}=\{0.1\}$.
} 
Figure 3 plots the CE for village, non-village and all observations using the output approach. Figure 4 shows a similar presentation using the expenditure approach. Table 5 presents the statistical summaries of cost efficiency. From the mean efficiency scores, an autonomous village is $22 \%$ more efficient than a non-autonomous village (kelurahan). This means that the autonomy status of the government can lead to efficiency. On the other hand, urban community (kelurahan) status is non-autonomous and entirely controlled by the upper tier of government; resulting in mean-efficiency scoresthat are lower than those of the autonomous village. However, a non-autonomous unit is $6 \%$ more efficient than an autonomous unit in its expenditure approach, which implies a smaller deficit/surplus and more care taken to balance expenditure. Through the lens of public spending, it is efficient, but it is worth noting that this approach does not represent the effectiveness of the expenditure.

Table 3. Efficiency Estimation and Its Determinants (Output Approach)

\begin{tabular}{|c|c|c|c|}
\hline Variables & $\begin{array}{l}\text { Autonomous } \\
\text { village group }\end{array}$ & $\begin{array}{l}\text { Non- autonomous } \\
\text { village group }\end{array}$ & $\begin{array}{c}\text { All (meta- } \\
\text { frontier) }\end{array}$ \\
\hline \multicolumn{4}{|c|}{ Panel 1: Meta-Cost Frontier Model } \\
\hline \multicolumn{4}{|c|}{ Dep.Var: Village revenue } \\
\hline \multirow[t]{2}{*}{ Educational infrastructure } & $0.09^{* * *}$ & $0.14^{* * *}$ & $0.10^{* * *}$ \\
\hline & $(0.01)$ & $(0.05)$ & $(0.01)$ \\
\hline \multirow[t]{2}{*}{ Health infrastructure } & $0.26^{* * *}$ & $0.19^{* * *}$ & $0.25^{* * *}$ \\
\hline & $(0.01)$ & $(0.08)$ & $(0.01)$ \\
\hline \multirow[t]{2}{*}{ Religion Related infrastructure } & $0.12^{* * *}$ & $0.25^{* * *}$ & $0.12^{* * *}$ \\
\hline & $(0.01)$ & $(0.07)$ & $(0.01)$ \\
\hline \multirow[t]{2}{*}{ Village co-ops } & $0.28^{* * *}$ & $0.13^{* * *}$ & $0.28^{* * *}$ \\
\hline & $(0.01)$ & $(0.03)$ & $(0.01)$ \\
\hline \multirow[t]{2}{*}{ Constant } & $2.96^{* * *}$ & $1.84^{* * *}$ & $2.92^{* * *}$ \\
\hline & $(0.08)$ & $(0.47)$ & $(0.08)$ \\
\hline \multicolumn{4}{|c|}{ Panel 2: Inefficiency Model $\mathrm{E}\left\{\exp \left(u_{i}\right) \mid \varepsilon_{i}\right\}$} \\
\hline \multicolumn{4}{|c|}{ Dep.Var: Inefficiency score } \\
\hline \multirow[t]{2}{*}{ Shares of micro-transfers } & $-11.23^{* * *}$ & $4.00^{* * *}$ & $-10.58^{* * *}$ \\
\hline & $(0.48)$ & $(0.66)$ & $(0.45)$ \\
\hline \multirow[t]{2}{*}{ Village representatives $(\mathrm{Y} / \mathrm{N})$} & 1.27 & -0.34 & 0.36 \\
\hline & $(1.14)$ & $(0.74)$ & $(0.73)$ \\
\hline \multirow[t]{2}{*}{ Apparatus per village family } & $20.53^{* * *}$ & $40.61^{* * *}$ & $20.57^{* * *}$ \\
\hline & $(1.10)$ & $(9.89)$ & $(0.01)$ \\
\hline \multirow[t]{2}{*}{ Leader's education } & 0.03 & -0.04 & 0.02 \\
\hline & $(0.03)$ & $(0.12)$ & $(0.03)$ \\
\hline \multirow[t]{2}{*}{ Vice-leader's education } & -0.03 & -0.1 & -0.04 \\
\hline & $(0.03)$ & $(0.12)$ & $(0.08)$ \\
\hline \multirow[t]{2}{*}{ Constant } & -1.86 & 1.99 & -0.91 \\
\hline & $(1.17)$ & $(1.32)$ & $(0.77)$ \\
\hline Observations & 15,101 & 362 & 15,463 \\
\hline Log-likelihood & $-18,000$ & -347.5 & $-18,419$ \\
\hline Lambda & 0.77 & 0.46 & 0.76 \\
\hline
\end{tabular}


Table 4. Efficiency Estimation and Its Determinants (Expenditures Approach)

\begin{tabular}{|c|c|c|c|}
\hline Variables & $\begin{array}{l}\text { Autonomous } \\
\text { village group }\end{array}$ & $\begin{array}{c}\text { Non- autonomous } \\
\text { village group }\end{array}$ & $\begin{array}{r}\text { All (meta- } \\
\text { frontier) }\end{array}$ \\
\hline \multicolumn{4}{|c|}{ Panel 1: Meta-Cost Frontier Model } \\
\hline \multicolumn{4}{|c|}{ Dep.Var: Village revenue } \\
\hline \multirow[t]{2}{*}{ Capital spending } & $0.31^{* * *}$ & $0.15^{* * *}$ & $0.30^{* * * *}$ \\
\hline & $(0.00)$ & $(0.02)$ & $(0.00)$ \\
\hline \multirow[t]{2}{*}{ Overhead spending } & $0.30^{* * *}$ & $0.42^{* * *}$ & $0.38^{* * *}$ \\
\hline & $(0.00)$ & $(0.03)$ & $(0.00)$ \\
\hline \multirow[t]{2}{*}{ Other spending } & $0.14^{* * *}$ & $0.07^{* * *}$ & $0.14^{* * *}$ \\
\hline & $(0.00)$ & $(0.03)$ & $(0.00)$ \\
\hline \multirow[t]{2}{*}{ Constant } & $0.70^{* * *}$ & $0.21^{* * *}$ & $0.70^{* * *}$ \\
\hline & $(0.01)$ & $(0.09)$ & $(0.01)$ \\
\hline \multicolumn{4}{|c|}{ Panel 2: Inefficiency Model $\mathrm{E}\left\{\exp \left(u_{i}\right) \mid \varepsilon_{i}\right\}$} \\
\hline \multicolumn{4}{|c|}{ Dep.Var: Inefficiency score } \\
\hline \multirow[t]{2}{*}{ Shares of micro-transfers } & $-2.72^{* * *}$ & $-6.14^{* * *}$ & $-2.74^{* * *}$ \\
\hline & $(0.05)$ & $(0.67)$ & $(0.05)$ \\
\hline \multirow[t]{2}{*}{ Village representatives $(\mathrm{Y} / \mathrm{N})$} & 0.05 & 1.63 & 0.04 \\
\hline & $(0.14)$ & $(1.26)$ & $(0.13)$ \\
\hline \multirow[t]{2}{*}{ Apparatus per village family } & $5.34^{* * *}$ & $31.60^{* * *}$ & $5.22^{* * *}$ \\
\hline & $(0.22)$ & $(9.81)$ & $(0.22)$ \\
\hline \multirow[t]{2}{*}{ Leader's education } & $-0.02^{*}$ & -0.08 & $-0.02^{*}$ \\
\hline & $(0.01)$ & $(0.15)$ & $(0.01)$ \\
\hline \multirow[t]{2}{*}{ Vice-leader's education } & 0.01 & -0.17 & 0.01 \\
\hline & $(0.01)$ & $(0.17)$ & $(0.01)$ \\
\hline \multirow[t]{2}{*}{ Constant } & $-0.84^{* * *}$ & 0.07 & $-0.83^{* * *}$ \\
\hline & $(0.15)$ & $(1.89)$ & $(0.15)$ \\
\hline Observations & 46,026 & 566 & 46,592 \\
\hline Log-likelihood & $-33,910$ & -465 & $-34,547$ \\
\hline Lambda & 0.34 & 0.45 & 0.36 \\
\hline
\end{tabular}

Table 5. Efficiency Summary

\begin{tabular}{llccc}
\hline & & $\begin{array}{c}\text { Autonomous } \\
\text { villages }\end{array}$ & $\begin{array}{c}\text { Non-autonomous } \\
\text { villages }\end{array}$ & All \\
\hline Mean & TE (Output based) & 0.80 & 0.58 & 0.80 \\
& TE (Expenditure based) & 0.68 & 0.75 & 0.68 \\
SD & TE (Output based) & 0.19 & 0.23 & 0.19 \\
& TE (Expenditure based) & 0.19 & 0.22 & 0.19 \\
Min & TE (Output based) & 0.02 & 0.02 & 0.01 \\
& TE (Expenditure based) & 0.00 & 0.02 & 0.00 \\
Max & TE (Output based) & 1.00 & 0.90 & 1.00 \\
& TE (Expenditure based) & 0.98 & 0.97 & 0.98 \\
& (Output based) & 15,101 & 362 & 15,463 \\
& (Expenditure based) & 46,026 & 566 & 45,592 \\
\hline
\end{tabular}

Notes: Efficiency scores are calculated using the inverse of the estimated cost inefficiency such as $\mathrm{CE}_{\mathrm{i}}=\mathrm{E}\left\{\exp \left(-u_{i}\right) \mid \varepsilon_{i}\right\}$ Source: Data analysis 


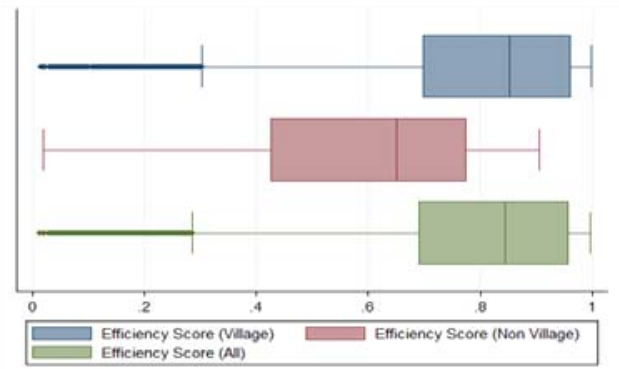

Source: Author' analysis

Figure 3. Distribution of Efficiency Scores (output based)

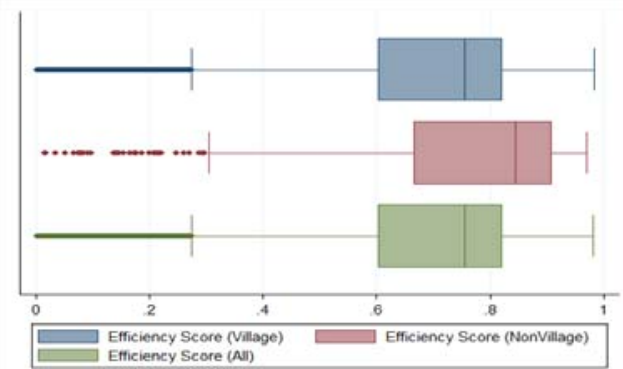

Source: Author' analysis

Figure 4. Distribution of Efficiency Scores (Expenditure based)

result implies that a percent of increase of village transfer shares cut around 2,67\%-2,77\% of inefficiency scores. By comparing the magnitude of the impacts of the village transfers, the village group has a lower magnitude than the non-village one, which implies village transfers positively affect government spendings' efficiency, especially for the non-village governments. Similar effects are observed with the expenditure approach. Figure 5 and Figure 6 show the relationship.

The existence of monitoring and representatives of the community on the villages' governing bodies should reduce inefficiency. The likelihood estimations do not report any significance. It seems that the presence of an adhoc representative does not have any effect. Figures 7 and 8 show that, for the distribution of CE by the availability of representatives, the result seems ambiguous since, from the graph, there is no significant difference in CE's distribution between an available representative government and the not-available one. The plausible explanation is that enlarging the participation of the community in the governmental process may increase the efficiency of spending. However, if the community's members are not well educated, the effect may be the opposite. Better-educated people may be also more altruistic as leaders, and thus they are less likely to engage in resources misappropriation (Mansuri \& Rao, 2012).

\footnotetext{
${ }^{8}$ Republika (2017), Sleman has a successfully managing village fund (Sleman dinilai sukses kelola dana desa). Retrieved from https://republika.co.id/berita/ekonomi/ desa-bangkit/19/01/17/plgwf3368-sleman-dinilai-sukseskelola-dana-desa

${ }^{9}$ Note that programming of frontier analysis regresses the Technical Inefficiency which takes the value one (efficient) to infinity (inefficient).
} 

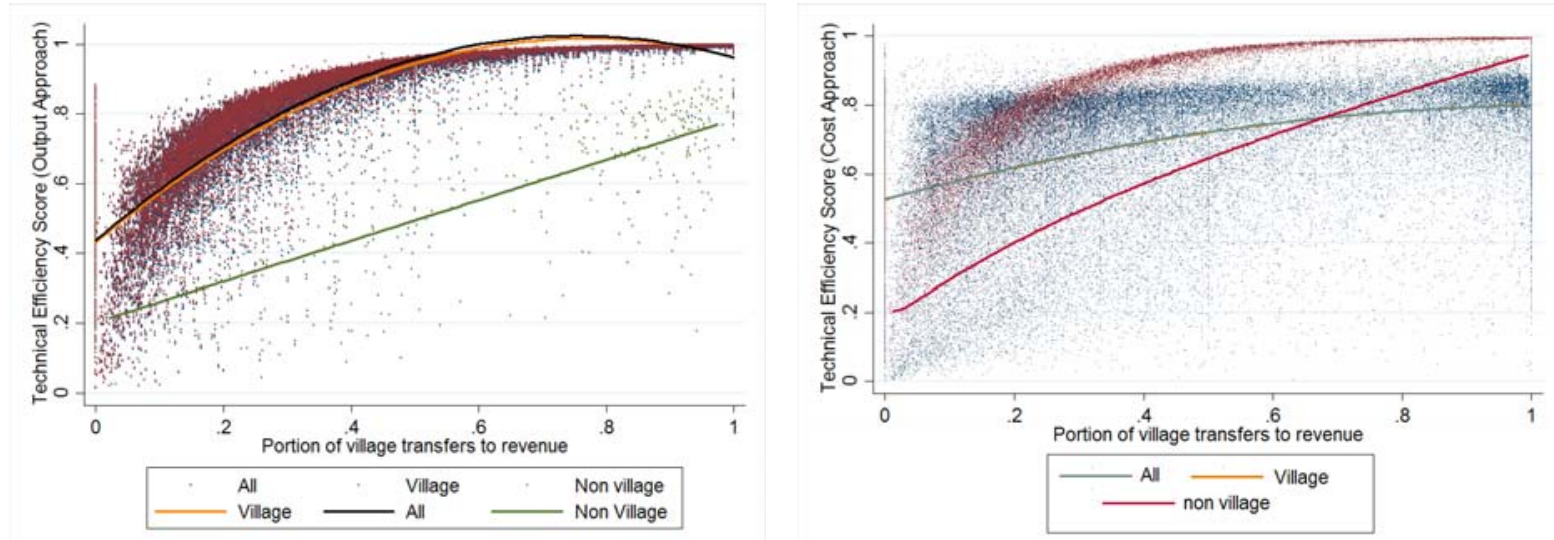

Source: Data analysis

Relation Between Efficiency Score and Portion of Village Transfer by Village Status

Figure 5. Output Approach

Figure 6. Expenditure Approach
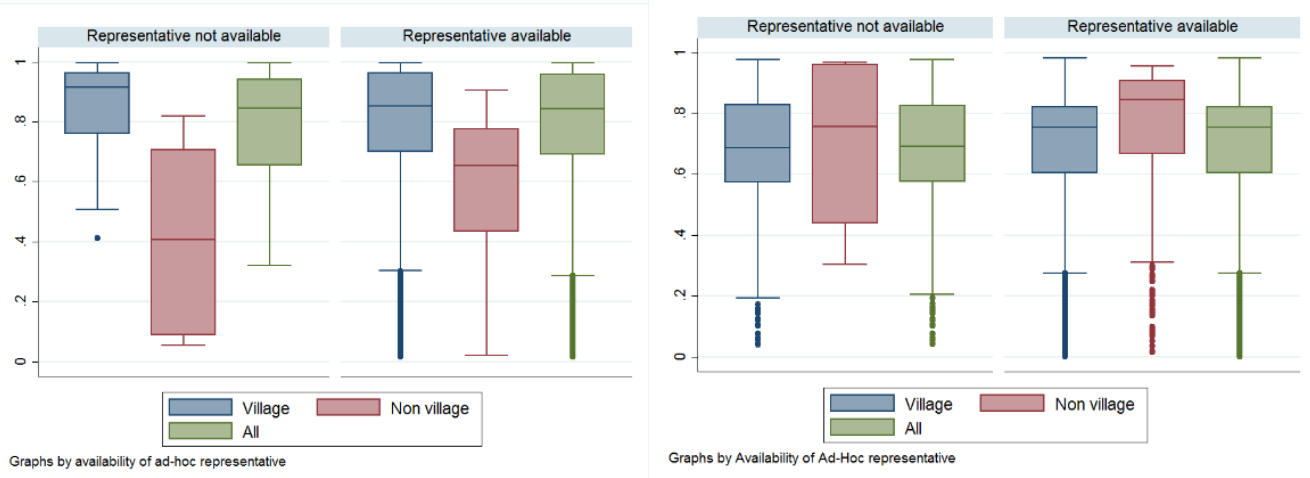

Source: Data analysis

CE distribution on representative not-available rural government (left part) and representative available rural government (right part)

Figure 7. Output Approach

The validation of the second hypothesis is about the correlation between expenditure efficiency and the size of the bureaucracy. Adding a unit of government officers per family increases output inefficiency by 20.57 units and expenditure inefficiency by 5.22 units, which implies that increasing the size of the rural government's administration distorts expenditure efficiency. The magnitude is greater for nonvillage governments where the difference of the coefficients is 20 points for the output approach and 26 points for the expenditure approach. This finding shows that increasing the numbers of apparatus leads to less efficient government
Figure 8. Expenditure Approach

spending, and the effect is greater for the nonautonomous government. The results confirm the second hypothesis, where an increase in the size of the bureaucracy leads to spending inefficiency. Kau \& Rubin (1981) and Treisman (2000) confirmed similar findings. Figure 9 and Figure 10 present the two-way plot showing a negative relation between the bureaucracy's size and its efficiency.

Finally, the third hypothesis, which seeks correlations between bureaucracy's capacity and expenditure efficiency. In Table 3, the education of the village leader and his/her deputy has no significant effect on production efficiency. In 
Table 4, the education of the leader, as a proxy of bureaucratic capacity, influences the inefficiency negatively. The impact of education only matters for the (autonomous) village government. These findings are aligned with Aspinall \& Rohman's (2017) recommendation, where the capacity of the bureaucracy improves the spending efficiency, especially when locals can elect their leaders according to their ability. Note that only autonomous village governments can hold local elections, non-autonomous villages cannot. For a non-autonomous village, the upper tier government directly appoints the village's leader.

\section{CONCLUSION}

Decentralization reforms in Indonesia reach a new level by acknowledging the autonomy of the village government, the smallest unit in the government structure. Following this reform, the central government allocates top-down transfers to the villages, yet these transfers are prone to corruption and inefficiencies.

The findings show that the villages could efficiently spend their expenditure, with effi-

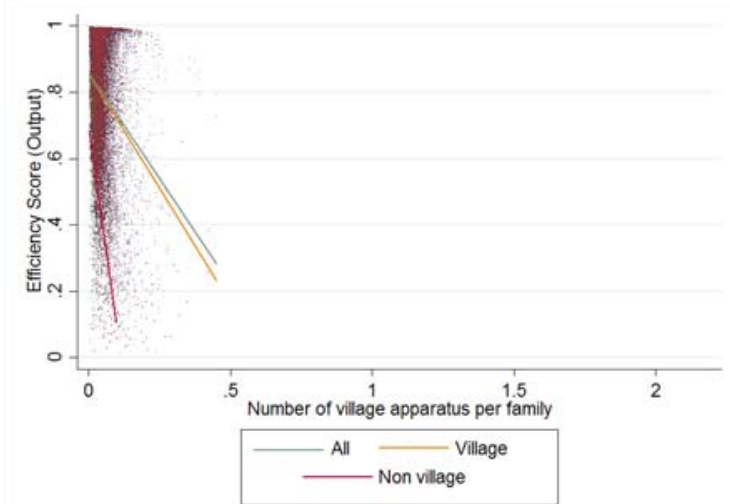

Source: Data analysis

Technical Efficiency of output approach (Y-axis) versus Size of Bureaucracy (X-axis)

Figure 9. Output Approach

Figure 10. Expenditure Approach

\footnotetext{
${ }^{10}$ Both Boetti et al. (2012) and De Borger \& Kerstens (1996) explore the efficiency of municipal/city governments by employing data envelopment analysis (DEA) and stochastic frontier analysis (SFA). These techniques produce the parametric and non-parametric measurement of inefficiency terms, albeit assuming there is a technology homogeneity among the observations. This paper uses a meta-frontier approach that allows for technology heterogeneity among the observations.
}

ciency scores above $68 \%$. The village governments perform better if they have autonomous status and have full control over their village transfers. Several factors may explain this efficiency. Increasing the number of bureaucrats diminishes village spending efficiency, as expected. In contrast, increasing the bureaucratic capacity appears to improve the spending efficiency, even though the statistical results are only convincing for the group of autonomous villages.

This study's contribution is twofold. As a pioneering move, Indonesia expanded its decentralization policy by granting autonomy to the sub-municipal administrations. Thus, given the experience and policy practice in Indonesia, this study is the first to explore the efficiency of spending by the autonomous sub-municipal governments. Second, the paper contributes by explaining the impacts of both the lump-sum grants and the bureaucracy on determining expenditure efficiency. This paper complements the works by Boetti et al (2012) and De Borger \& Kerstens (1996). ${ }^{10}$

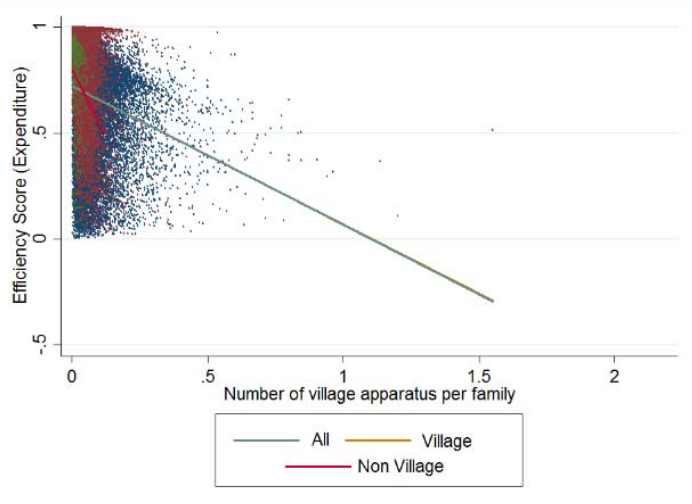




\section{STUDY LIMITATION AND POLICY IMPLICATION}

This study has three major limitations. First, this study employed village survey data from the National Statistics Agency. The budget data contains self-reporting assessments from the village governments, which arguably need to be validated by the upper tier governments. Therefore, the problem of measurement errors may arise during the empirical analysis. The solution to correct this problem is to combine the maximum likelihood estimators in the first step to estimate the efficiency scores, and use instrumental variable analysis in the second step to evaluate the efficiency determinants. Second, this study limits the measurement of government efficiency to the view of parametric cost efficiency, while assuming the price of providing public goods is indexed. However, it does not apply in real practice since the government's spending efficiency may come from the result of effective management, organization, and cheaper costs for delivering public services. Third, the paper uses the village leaders' and deputy leaders' education as the representative variable for the villages' bureaucratic capacity, which is challenging. The bureaucracy's capacity is a general concept, which needs a comprehensive measurement. A detailed study to measure the broad meaning of bureaucratic capacity should take place as a milestone in future research agendas, which later could be associated with the village government's efficiency.

The results suggest several policy implications, for instance creating a lean government structure for village governments and focusing on capital expenditure and physical infrastructure. Extending decentralization to the village level and increasing village transfers are appropriate policies; nevertheless, strengthening the current regulations, capacity and institutions are indispensable.

\section{REFERENCES}

Akai, N., Sato, M., \& Yamashita, K. (2001, February). Intergovernmental transfers in Japan and soft budgets. In International Symposium on Intergovernmental Transfers in Asian Countries: Issues and Practices, Asian Tax and Public Policy Program, Tokyo (Hitotsubashi University).

Antlöv, H. (2003). Village government and rural development in Indonesia: The new democratic framework. Bulletin of Indonesian Economic Studies, 39(2), 193-214. DOI:

$10.1080 / 00074910302013$

Antlöv, H., Wetterberg, A., \& Dharmawan, L. (2016). Village governance, community life, and the 2014 village law in Indonesia. Bulletin of Indonesian Economic Studies, 52(2), 161-183. DOI: 10.1080/00074918.2015.1129047

Aspinall, E. (Ed.). (2003). Local Power \& Politics in Indonesia. Flipside Digital Content Company Inc.

Aspinall, E., \& Rohman, N. (2017). Village head elections in Java: Money politics and brokerage in the remaking of Indonesia's rural elite. Journal of Southeast Asian Studies, 48(1), 31-52. DOI: $10.1017 / \mathrm{S} 0022463416000461$

Battese, G. E., \& Rao, D. P. (2002). Technology gap, efficiency, and a stochastic meta-frontier function. International Journal of Business and Economics, 1(2), 87.

Battese, G. E., Rao, D. P., \& O'donnell, C. J. (2004). A meta-frontier production function for estimation of technical efficiencies and technology gaps for firms operating under different technologies. Journal of Productivity Analysis, 21(1), 91-103. DOI:

10.1023/B:PROD.0000012454.06094.29

Battese, G. E., \& Coelli, T. J. (1992). Frontier production functions, technical efficiency and panel data: With application to paddy farmers in India. Journal of Productivity Analysis, 3(1-2), 153-169. DOI: 10.1007/BF00158774

Boetti, L., Piacenza, M., \& Turati, G. (2012). Decentralization and local governments' performance: How does fiscal autonomy affect spending efficiency? Finanz Archiv/Public Finance Analysis, 68(3), 269-302. DOI: 


\section{$10.1628 / 001522112 \times 653840$}

Borge, L. E., Falch, T., and Tovmo, P. (2008). Public sector efficiency: the roles of political and budgetary institutions, fiscal capacity, and democratic participation. Public Choice, 136(34), 475-495. DOI: 10.1007/s11127-008-9309-7

De Borger, B., \& Kerstens, K. (1996). Cost efficiency of Belgian local governments: A comparative analysis of FDH, DEA, and econometric approaches. Regional Science and Urban Economics, 26(2), 145-170. DOI: 10.1016/01660462(95)02127-2

Hlepas, N., Kersting, N., Kuhlmann, S., Swianiewicz, P., \& Teles, F. (2018). Introduction: Decentralization beyond the municipal tier. In SubMunicipal Governance in Europe (pp. 1-24). Palgrave Macmillan, Cham.

Hjalmarsson, L., Kumbhakar, S. C., \& Heshmati, A. (1996). DEA, DFA and SFA: A comparison. Journal of Productivity Analysis, 7(2-3), 303327. DOI: 10.1007/BF00157046

Kau, J. B., \& Rubin, P. H. (1981). The size of government. Public Choice, 37(2), 261-274. DOI: $10.1007 / \mathrm{BF} 00138246$

Kumbhakar, S. C., \& Lovell, C. K. (2000). Stochastic frontier analysis. Cambridge University Press.

Lewis, B. D. (2015). Decentralizing to villages in Indonesia: Money (and other) mistakes. Public Administration and Development, 35(5), 347359. DOI: $10.1002 /$ pad.1741

Mansuri, G., \& Rao, V. (2012). Localizing development: Does participation work? The World Bank.
Martinez-Bravo, M. (2014). The role of local officials in new democracies: Evidence from Indonesia. American Economic Review, 104(4), 1244-87. DOI: 10.1257/aer.104.4.1244

Maharjan, K. L. (2014). Capacity of rural institutions in implementing decentralized development in Indonesia: Case of three villages in Purbalingga District, Central Java Province. In Communities and Livelihood Strategies in Developing Countries (pp. 143-167). Springer, Tokyo.

Moesen, W., \& Van Cauwenberge, P. (2000). The status of the budget constraint, federalism and the relative size of government: A bureaucracy approach. Public Choice, 104(3-4), 207-224. DOI: 10.1023/A:1005116413195

Niskanen, W. A. (1968). The peculiar economics of bureaucracy. The American Economic Review, 58(2), 293-305. Retrieved from http://www.jstor.org/stable/1831817

Roudo, M., \& Chalil, T. M. (2016). Depolarization in delivering public services? Impacts of minimum service standards (MSS) on the quality of health services in Indonesia. Journal of Regional and City Planning, 27(1), 1-15.

Smoke, P., \& Lewis, B. D. (1996). Fiscal decentralization in Indonesia: A new approach to an old idea. World Development, 24(8), 1281-1299. DOI: 10.1016/0305-750X(96)00042-3

Treisman, D. (2000). The causes of corruption: A cross-national study. Journal of Public Economics, 76(3), 399-457. DOI: 10.1016/S00472727(99)00092-4 